\title{
The Three Axes of Sociological Practice: The Case of French Quebec ${ }^{1}$
}

\author{
JEAN-PhiLIPPE WARREN
}

\begin{abstract}
In the debate surrounding Michael Burawoy's plea for public sociology, it is all too often presented as the opposite of the detached, purely objective observation of society. But sociology is not torn between these two poles: the political and the scientific/empirical. Rather, the discipline is structured around three fundamental axes or dimensions: professional, descriptive, and political, embodying three essential aims which, in turn, constitute the respective roles sociology can play in academia and society depending on the specific publics the discipline seeks to address. Acting as professionals, sociologists try to attain prestige by accumulating social or symbolic capital among their colleagues. If they serve science for science's sake, they find their reward in the advancement of knowledge. If they adopt an activist political stance, they measure the value of their work on a different scale. This paper focuses specifically on Frenchlanguage sociology in Quebec from the late 19th century to 1970 and argues that the dilemma of juggling these three axes, aims, and roles is one which has deeply influenced not only the discipline as a whole but the generations of Quebec sociologists who have attempted to balance these dimensions in their scholarship. There were three basic schools or approaches during this period, each embedded in the social conditions of its time. Sociologists' public engagement depended on specific historical conditions much more than it did on personal preferences.
\end{abstract} Keywords: public sociology; French-language sociology; Quebec sociology

Résumé. Dans le débat autour de l'appel, lancé par Burawoy, en faveur d'une sociologie publique, celle-ci est par trop souvent présentée comme l'opposé d'une observation purement objective de la société. En fait, la sociologie n'est pas déchirée de manière dichotomique entre les pôles politique et savant, mais elle est plutôt articulée autour des trois dimensions fondamentales suivantes : professionnelle, descriptive et politique. Ces dimensions sont définies par les trois objectifs essentiels qui constituent les rôles que la sociologie est appelée à jouer dans les établissements d'enseignement supérieur et la société en fonction de ses différentes sollicitations. En tant que professionnels, les sociologues tentent d'atteindre une position de prestige en accumulant un capital social ou

1. I warmly thank Rick Helmes-Hayes and Neil Mclaughlin for their suggestions and criticisms on an earlier draft of this article. 
symbolique. S'ils décident de servir la science pour la science elle-même, ils trouveront leur récompense dans l'avancement des connaissances. S'ils adoptent une posture militante, ils mesureront la valeur de leurs réalisations sur une autre échelle encore une fois. Cet article étudie la sociologie québécoise de la fin du 19e siècle jusqu'à 1970 et soutient que la difficulté à conjuguer ces trois dimensions, objectifs et rôles a non seulement influencé la discipline dans son ensemble mais qu'elle a aussi eu un impact réel sur les générations de sociologues qui ont cherché à équilibrer ces tensions dans leurs carrières. Au Québec, on peut identifier trois grandes écoles ou approches pendant la période qui nous concerne, chacune aux prises avec des conditions sociales spécifiques. C'est en ce sens que l'on peut dire que l'engagement public des sociologues a toujours beaucoup plus dépendu du contexte particulier dans lequel ils ont dû s'insérer que de leurs préférences personnelles.

Mots clés: sociologie publique; sociologie québécoise

D) ublic sociology is all too often presented as the polar opposite of the detached, purely objective observation of society (Clawson et al. 2007). Such a portrayal is misleading, for it gives credence to the idea that academic sociology is torn between two extremes, the political and the empirical poles. In this article I will not contest this divide from within. I shall not, for instance, claim that sociology is inherently politicized, each epistemology necessarily proposing a different ontology (Blau and Smith 2006). Considering the problem differently, and referring to a historical period spanning from the late 19th century to about 1980 (Fournier 1986; Warren 2003), I propose a three-faceted portrait of sociology. In my view, the discipline is structured around not two but three fundamental axes or dimensions: professional, descriptive, and political, embodying three essential aims. In turn, these constitute the respective roles it can play in academia and society depending on the specific publics it seeks to address. In his much debated ASA 2004 presidential speech, Burawoy (2005) claimed that public sociology should be defined by its audience, whether academic (professional, critical) or extra-academic (policy and public). Without directly challenging this view, I intend in this paper to illustrate how the scholar's individual positioning offers a slightly different perception of public sociology than the discipline's external dynamics.

The question then becomes: From whom are academic sociologists seeking recognition? Acting as professionals, they try to attain prestige and approval by accumulating social or symbolic capital. If they serve science for science's sake, they find in the advancement of knowledge its own reward. If they adopt a political stance and seek to transform society through activist strategies, they measure the value of their work on a different scale yet again. Therefore, as I demonstrate below, the 
dilemma depicted in this article - juggling these three axes, aims, and roles - is one which affects not only the discipline as a whole but also those generations of Quebec's sociologists who have attempted to balance these dimensions in their scholarship. Such a historical perspective serves three purposes. First, by talking about three dimensions or axes of sociology, it puts a new "spin" on the debate between professional, scientific sociologists on the one hand and the public sociologists on the other. Second, it adds a historical element to a debate which often focuses almost exclusively on the contemporary aspects of the problem. Third, it contributes to our understanding of the place that sociology occupies in French-language Quebec, where the "public sociology debate" has been around in one form or another since the very beginning. The lessons one can draw from the understanding of its unfolding will serve as a reminder that sociologists' public engagement depends on specific historical conditions much more than it does on personal preferences. The willingness to participate in Quebec society's debates has always been linked to different schools of sociological thought and the broader social conditions affecting the work of social scientists. Personal "commitment" and "sacrifice," as suggested by Burawoy (2005:25), may not be considered enough by those who know the complex progression of public sociology in Quebec.

\section{Three Fundamental Axes of the Sociological Craft}

Before I describe how they played out in the course of Quebec's development, let me briefly describe the three axes that structure academic sociologists' activities. I acknowledge the simplification that such a short presentation entails but it serves as a starting point for better understanding how French Quebec sociologists have historically tackled the professional, critical, and "positivistic" dimensions of their position. What is at stake here is not so much a "division of labour" (Burawoy 2004:1611; 2005:9-11) among interdependent sociologies, but a "structural division" related to the relative autonomy of three specific social fields (Bourdieu 1975): societal, institutional, and scientific (Fournier 1985:418).

In the first place, sociologists practice a trade. Sociology requires the use of methods, techniques, and theories which did not really exist in Quebec at the end of the 19th century, for want of a solid intellectual tradition. These methods and theories were inevitably borrowed from Europe and the United States to satisfy the needs of scientific enquiry, although they were on occasion slightly adapted to the French Canadian context. Léon Gérin, for instance, became a disciple of the Tourvillian 
branch of Le Play's sociology, after a six-month stay in Paris. Likewise, Jean-Charles Falardeau studied at the University of Chicago under the supervision of Everett Hughes before accepting a teaching position at Laval University. Not only did Falardeau and his colleagues train their students to become serious and rigorous scientists, but they were always under relative pressure to perform by publishing in top-ranked, peer-reviewed journals, giving key-note speeches, participating in international conferences, and so on. What is important to consider here is the autonomy between, on the one hand, their contribution to the progress of sociology as a science and their involvement in policy formulation and social group formation, and, on the other hand, their success in establishing themselves as prominent figures in the field. Sociologists gain recognition not only by publishing state-of-the-art research. On the tortuous road to recognition, social and symbolic capitals constantly interfere with scientific accomplishments (Bourdieu 2004). The desire to pursue a prestigious career and adopt what Burawoy calls a "professional self-defense" (2004:1605) will determine choices that may not be in the interests of science or society. Giving papers in Paris or Berkeley, agreeing to serve as department chair, publishing articles in Le Monde diplomatique or Harper's Magazine, being invited on television to comment on the news, all come with some prestige but say nothing in themselves about a sociologist's commitment to politics or science. As Bourdieu noted well, usefulness, truth, and prestige are three separate notions in sociologists' day-to-day practice (see Heilbron, Lenoir and Sapiro 2004:9).

Second, sociology is based on a premise of objectivity, by which I simply mean that sociologists have the obligation to observe and describe reality as they see it, seeking to impartially understand the deeper functioning of a society. The insistence on the empirical aspect of a sociologist's work often has been heralded as the very core of a sociologist's task. The journal Recherches sociographiques, founded in 1960, offers, in its very title, testimony of this perspective (Gagnon 1988:107).

Recherches sociographiques [declared Fernand Dumont and Jean-Charles Falardeau in its first issue] wishes to consider our society at the ground level, so to speak. This is the reason why the reader will find here some very empirical monographs. Some articles will even be of an exclusively descriptive character. (Dumont and Falardeau 1960:4)

The idea put forth in this first issue was that sociologists could perform their work without conceiving any other goal than a pure and untainted description of reality. Serious epistemological qualifications of science's objectivity have been formulated over the years but French Quebec sociology has periodically insisted forcefully on the detached quest for facts. 
According to such a view, science, whatever the aim or the purpose, should be its own reward.

Third, sociology has been associated with a history of social engagement. Many French Quebec sociologists have repeated, after Durkheim, that sociology would not be worth an hour of labour if it could not serve to better society (Durkheim [1893] 1967:3). They have been tempted by proselytism, nationalism, socialism, corporatism, Marxism, social democracy, and many other combinations of these ideologies, and, more generally, by a desire to transform the world, to become, as so many have confessed at one time or another in their careers, "agents of social change" (Fournier 1991:473). Sociologists have been politically active, incorporating as a fundamental dimension of their practice a drive towards the improvement of humankind and trying to translate their most abstract or empirical findings into a denunciation of injustice and exclusion (Gagné and Warren 2005). Fernand Dumont emphasized how impartial truth-seeking was only one facet of a sociologist's work, and that he or she was ultimately bound by the obligation of relevancy (Dumont 1981; 2000:102-104). A science completely turned inward would be, according to Dumont, a supreme hoax, designed to enhance the scientist's scholarship at the expense of humankind's needs. Such an insistence on the imperative to serve society is understandable in the context of a strong belief in the continuous evolution of society, as commonly expressed in typologies such as "traditional society/technological society," "folk society/urban society," or "capitalist mode of production/communist mode of production" (Couture and Denis 1994). From Léon Gérin's declarations in the $1910 \mathrm{~s}$

It seems that the only reasonable and satisfying solution [to our nation's prosperity] is French Canadians' fast and complete adaptation to the conditions of the modern world, utterly different from the previous era....

to Gilles Bourque's and Nicole Laurin's words in the 1970s

We believe in the necessity and urgency of clearly orienting the revolutionary movement towards what has been commonly called the national question....

one can follow a line of strong commitment to the Francophone group's destiny (Fournier 2001; Gagné and Warren 2005).

Obviously, these three dimensions of sociology can clash, and have indeed come into conflict on numerous occasions. Framed in its most schematic form, sociologists may pledge to dedicate themselves to one or the other of these allegiances: their career, knowledge for knowledge's 
sake, or society. At one extreme, they may dismiss the scientific or social relevance of their work, and primarily seek professional advancement. At another extreme, sociologists may only care about the accumulation of neutral and monographic depictions of reality, notwithstanding any professional incentive or social relevance. They will entertain the idea of arriving at a pure description of reality formulated in the absence of social or self-interested goals, driven only by the Promethean ideal to fully explore and elaborate an area of knowledge and incidentally work towards the advancement of science (even though, as Burawoy observes, failing to take a stance with respect to one's world already is a political gesture - 2005:1606). Finally, the ambition to arrive at an objective description of reality and the will to turn sociology into an instrument of self-promotion may well be overwhelmed, in some cases, by an attempt to serve a conservative or progressive critique of society.

In Quebec, sociology has known very different mixtures and dosages of these three traits. Although French Canadian sociology can never be compared to German, French, or American sociological traditions in terms of its richness and influence, its main protagonists have been caught up in the same set of questions, and they have been faced with the same fundamental challenges as their European and American counterparts. The fashion in which they responded to the intrinsic dilemma of combining the professional, scientific, and political aspects of their work is instructive vis-à-vis a society's efforts to resolve this potential conflict by constantly redefining and rearticulating the notions of career, engagement, and science according to specific historical context. Burawoy's interpretation of public sociology can be enriched by looking back at French Canadian history, especially considering that, for the better part of the 20th century, empirical research was undervalued and universities were dramatically underfunded, whereas, interestingly, public engagement was widely expected from Quebec social scientists (Warren 2003; 2008). The difficulty in performing empirical work or in developing an academic career left the door to social involvement wide open.

The overview of the history of French Canadian sociology presented here begins with the works of Léon Gérin, at the turn of the 20th century, and ends in the 1960s with the triumph of the "Laval School." I admit that this chronological presentation is highly schematic, omitting many nuances of the overall portrait, but the objective of this article is not to draw a fine and detailed picture of the history of French Canadian scientific traditions, which has already been done (Fournier 1986; Warren 2003). Rather, it is to provide a synthetic view of different epistemes by addressing the question of how early sociologists interpreted the simultaneous obligation to work towards political, personal, and scientific ad- 
vancement. Contemporary scholars are still debating this question. Returning to old and dusty work may benefit those trying to understand the intricate relationships between the three essential aspects of sociological practice - a reminder that, amongst the diversity of social phenomena which sociologists consider worthy of their attention, lies sociology itself, one of many manifestations of a society's consciousness.

\section{The Tourvillian Branch of the Le Playsian Sociology}

Regarded as the founding father of French Canadian sociology, Léon Gérin (1863-1951) has often been depicted as a scientist whose foremost concern was the collection of facts (Carrier 1960). In a letter written during a stay in Paris, in 1886, he declared that he had discovered in the work of Frédéric Le Play a natural science of society which he spontaneously associated with geology or botany. "Du positif! Du positif! Du positif!" he declared enthusiastically to underscore what had attracted him to Le Play's writings. Like most Victorian thinkers, he regarded sociology as a science in its purest sense: detached from moral considerations and untainted by political prejudices. For him, understanding society began by abandoning preconceived ideas and "multiplying personal observations, humbly, in minute details" (Gérin 1895). In a time when French Canada was consumed by religious quarrels and relentless political rifts, following the 1867 compact, did not social science promise to arrive at rigorous and unbiased knowledge?

The observation of reality required the formulation of a rigorous method, which Le Play and his followers called the "family monograph method." According to them, only family monographs enabled systematic field work and allowed for a fully coherent categorization of findings. To understand a society, researchers had to study specific families, just as botanists described different species of flora (Kalaora and Savoye 1989). Individual persons were deemed irrelevant; what mattered were family types, and these types existed in limited number. In the entire history of humanity, Le Play's disciples recognized only the communitarian family, the particularistic family, and the unstable family, and he classified them historically according to their more (or less) progressive nature (Méline 1912). His typology was also, therefore, a teleology, rooted in the assumption that the evolution of humankind followed a rigid path towards an inescapable form of universal social organization.

Gérin saw in the situation of the French-Canadian group, lost in a rapidly industrializing world, a stage in this typology. While Englishspeaking peoples were building workshops and factories, launching col- 
onial ventures westward, and raising their children in the spirit of an individualistic and fast-changing society, French Canadians refused to abandon their ancestors' customs. Raised in the warm comfort of the communitarian family, they did not embrace the modernist entrepreneurial spirit which was the basis of the American people's success (Périer 1951). They ended up leaving to others - chiefly British and American outsiders - the opportunity to create business enterprises where the Francophone would eventually seek poorly paid jobs. The FrenchCanadian society contemplated by Gérin at the beginning of the 20th century consequently presented some vivid contrasts with the rest of the continent:

primitive people in contact with a civilised people, communitarian people under the pressure of a particularist people, peasants stunned in their isolation, while the urban centres already resonate with new commercial and industrial developments. (Gérin 1913:ix)

Desperately lagging behind the rest of North America, French speakers were handicapped by their family organization and their educational system.

Gérin did not intend to tolerate such a state of affairs. Failing to embark on the train of progress, his compatriots were collectively losing ground in the struggle for the "survival of the fittest." It did not suffice to find solace in the fact that they studied their classics in colleges. With each passing year, they were plunged deeper into misery. To remedy this situation, sociology was useful for, according to Gérin, this discipline could not only identify the ills, it could prescribe the medicine. It represented, in this respect, an instrument of national liberation. "Let us popularise social science," argued Gérin, "and social science will save us" (Gérin 1905:81). In constantly insisting on the positivism of Gérin's sociology, one risks misunderstanding the scientific project that he put forth. An explicit utopia nourished his scientism. Duplicating the "moral positivism" that one can find at the root of Le Play's sociology, Gérin turned the analysis of society into a wedge to fundamentally transform his people. And his critique could be at once moral and scientific because it was connected to a belief in the evolutionary nature of societies. Just as Darwin did not succumb to any ideological bias when he formulated the existence of a "struggle for life," Gérin might have argued, social scientists could underscore the same struggle between nations without advocating a personal cause. The social fact was moral to the extent that the political nature of society was an undisputable fact in itself. His sociological observations were subsequently linked to an underlying teleological prescription. 
If there is a notable fact in our modern epoch, it is the stagnation and disappearance of societies belonging to the communitarian type (where private initiative is suppressed) with the advance of societies belonging to the particularist type (where private initiative is freely and strongly exercised). It is toward the particularist type, and not toward the communitarian type, that the nations of the universe are evolving, some rapidly, some slowly. It is toward the particularist type that Providence is guiding humanity. (Gérin 1905:82-83)

Judged by today's standards, Gérin's ambitions for social scientific training were more than modest. He thought that if the rudiments of sociology could be taught to fathers, teachers, and businessmen, then these members of the French Canadian elite would slowly instil particularistic lessons in the minds of their children, students, or workers. Such an education would only mildly insist on methods and theories, and would focus much more on the individual qualities required to perform in the modern world. The entire nation would receive, on top of a minimal scientific training, an initiation in which initiative and industry would be privileged. This moral edification would progressively eradicate the rampant laziness which, according to Gérin, too often plagued French Canadian schools and families. This is the reason why, in the circle he founded in Ottawa in 1905, Gérin attempted to popularize Le Play's social science among a small group of enlightened bureaucrats, lawyers, journalists, politicians, and priests, rather than pursue a career at the university level (he never gave an academic course). Such an attitude is not unique to him; in France, Le Play's disciples were reluctant to enter institutions of higher learning, preferring to disseminate their knowledge through more modest intellectual venues (Kalaora and Savoye 1989). Like his French colleagues, Gérin preferred to preach by example, personally showing the way to modernity by engaging in manual work on the farm he bought and where he eventually established himself. People would see, just by looking to him, the benefit of listening to the lessons of social science. Indeed, the last chapter of his final book, Le Type économique et social des Canadiens, constitutes a biographical account of what he achieved in encouraging the progress of agricultural techniques in a small Quebec village (Gérin 1938:183-218).

Although the connection between the scientific and critical aspects of Gérin's work is straightforward (his observations are embedded in eschatology), the professional aspect of his practice seems neglected. He was not interested in finding a niche for sociologists within French Canadian institutions, but was content for them to provide helpful advice for people to follow. He never sought any role in government and never occupied a position at Laval University. Indeed, he wrote all of his articles 
in his leisure time. The same can be said of Le Play's other Canadian disciples such as Stanislas Lortie (priest), Errol Bouchette (civil servant) or Fernand Rinfret (journalist). On the one hand, Gérin's interpretation of Le Play's sociology made him cautious of relying on institutions to encourage initiative. He was led to believe in the ideology of the self-made man, and could not look without some reluctance to more collective means of social organization. Le Play's particularist theory made him an individualist in real life. On the other hand, having more or less reduced sociological theory to a simple moral script, Gérin sought to disseminate his knowledge as a modern gospel, assigning to sociology very humble goals in terms of career opportunities. In his mind, a sociologist was a teacher, a priest, a bourgeois, or a father who understood the universal laws governing human history and could therefore teach the particularist family's values of initiative and hard work to his students, flock, workers, or offspring. "It is only through a patient individual propaganda exercised in the limits of the private sphere that our economic and social progress will be accomplished" (Gérin 1908:4). By taking guidance from social science, social elites would lead the French Canadian people to higher standards of living, morally, intellectually, and economically, and, thus, prevent the continued decline of French Canada. Having read a few books on the subject, any dilettante knew more than enough to begin teaching sociology by setting the right example and morally uplifting those around him. He or she became a pastor, but of a scientific type, looking to salvation not in heaven but in industry, and counselling French Canadians to act appropriately as individuals if they wanted to survive as a collective entity.

\section{Doctrinal SociologY}

At the turn of the 20th century, the Quebec clergy took a more active role in organizing the social domain, managing workers' unions, youth associations, newspapers, colonial ventures, and so forth. Religious figures became such a familiar feature of the social landscape that some commentators began talking of Quebec as a "priest-ridden province." In this context of growing clericalism, it was not a surprise that the sociological cohort immediately following the Tourvillian School belongs to a stream of thought that was overtly Roman Catholic (Routhier 1981). In contrast to Gérin, who situated himself within the liberal ideology of the "Rouges" (Lamonde 2004), the "doctrinal sociologists" derived their basic principles from the teachings formulated in pontifical encyclicals, and in particular from Rerum Novarum, published in 1891. According to 
them, Marx and Durkheim were dangerous revolutionary atheists who misconstrued the social world as a place of conflict and arbitrariness. Only the Catholic Church's teachings rightly portrayed human individuals as persons afflicted by original sin, reaching for salvation.

Doctrinal sociologists did not completely turn away from facts and figures but, in contrast with the long and monotonous empirical descriptions that readers find in Le Play's monographs (where even the price paid for a pair of socks is duly listed), they appear much less empirical and, consequently, much less scientific (Fournier 1986). They did not believe in the power of field work to uncover a truth that was already revealed in the Pope's preaching. The "social question is a moral question" (Montpetit 1907:286), they repeated, and, consequently, the resolution of the social question belonged properly to the Roman Catholic Church. They did not need researchers to uncover previously unknown facts and build from these findings vast theoretical systems, such as those proposed by Pareto or Weber. Convinced that the Church's social doctrine held an eternal truth, they tried more prosaically to apply and adapt Catholic teachings to the specific French Canadian context (Dupuis 1991), an approach that gave a strong deductive twist to their publications. They started their books and articles by fleshing out Catholic philosophical and theological principles and ended with some social facts corroborating these premises (Lévesque 1983:357).

The Catholic conception of science included the Church's distinction between body and soul (Lamonde 1980). Accordingly, true science had to be at once "physical" and "spiritual," or, if one prefers, "empirical" and "moral." It had to include some data collection but more importantly it had to explicitly lay out a moral understanding of the very nature of society. Sociology, presented as the positive study of collective life, always extended itself into a social philosophy turned towards the reaffirmation of humankind's divine ends. Indeed, if the analysis of society's functioning naturally led to an effort to improve its workings, then sociologists had to be guided in their work by a proper appreciation of what an ideal society would look like. "Social science is inseparable from morality.... A normative social science seeks to establish a social order and any social order is necessarily a moral order" (Delos 1934:9). But morality was not to be attained by following a set of rules and methods. Empirical science was clueless when it came to elaborating the plan for a good society or drawing the vision of a good life. Only the Catholic Church, claimed the doctrinal sociologists, could offer the eternal and universal morality upon which a complete and reconciled science of society would base its objective exploration of values, structures, or institutions. "If there is an objective moral, it is that of the Angelic Doctor [Thomas Aquinas]. It is 
an adequate expression of reality" (Robert 1922:100). If the task was to apply Thomas Aquinas' teachings to French Canadian realities, it is not surprising that this approach gave a very idealistic touch to the doctrinal sociologists' writings. In the 1930s, morality and society were worlds apart; the Church's preaching continued to be traditional (insisting on a paternalistic family, realism in the arts, repressed sexuality, colonization, corporatism, etc.) while French Canadian society was modernizing itself at a rapid pace (industrialization, urbanization, consumer culture, etc.). It seems that, at the time, the only way to salvage a Catholic morality - a morality increasingly challenged by French Canada's development was to sacrifice altogether the study of facts.

Such an abandonment of facts may not have been, in the doctrinal sociologists' eyes, as absurd as it seems. Writing in the 1930s, in the shadow of the Depression and the rise of fascism, it was evident to them that modern society had entered an irremediable crisis. Under such circumstances, why would sociologists waste any time writing long and useless factual descriptions of a doomed world (Warren 2002)? They felt it urgent to transform the world rather than dutifully analyzing an old and collapsing social order. Whereas the Marxists wished to revolutionize society in order to change humankind, doctrinal sociologists hoped to convert humankind in order to revolutionize society, an approach that again led them back to the Roman Catholic teachings. They wanted to reach the souls of the people, just as much as they wanted to modify the structures of society. They applied the Church's evangelical methods to their sociological practices, believing that by converting people one by one society would be eventually transformed. For example, after a detailed and quasi-Marxist analysis of class struggles in French Quebec, Esdras Minville, professor at the École des hautes études commerciales, concluded an article by encouraging owners and workers to listen to the Church's commandments and love each other instead of fighting against one another (Minville 1938). In 1920, Father Tardif declared with great seriousness that Eucharist would vanquish social inequalities and that "the reconciliation between classes will only be realized at the feet of the tabernacle and in the kiss of the communion" (Tardif 1920:5).

Long and fastidious analyses of society were not felt necessary for another reason. What doctrinal sociologists attempted to demonstrate seemed in their minds to be obvious. There was no need to convince their audience that liberalism was bankrupt and that continued pursuit of the same failed policies would only bring French Canada closer to collapse. A few statistics on unemployment in the 1930s sufficed. Did they have to prove that the economic quagmire primarily affected French Canadians? They needed only to open a telephone book and count the number of 
companies that bore a French name. The latter example is not fictitious; this is how Victor Barbeau proceeded to measure the lack of control that French Canadians enjoyed over the provincial economy.

Take a walk along the streets of Montréal, [he wrote in his book's introduction] go to the regions, knock on every door, read the signs.... Despite the gilt of our living rooms, the tinwork of our churches, we are poor, appallingly poor. We are proletarians, labourers, cannon-fodder. (Barbeau 1936:26)

L'Action nationale (a magazine directed by Lionel Groulx) launched many inquiries, some statistics were published by L'École sociale populaire (an institute designed to stimulate debates around certain social questions), les Semaines sociales (an annual meeting of prominent intellectuals) organized seminars on various social problems, but seldom did the publications venture beyond the elaboration of a few facts, simply because there was no need. Doctrinal sociology paid little attention to empirical research for that very reason.

If the objective study of French Canadian collective life did not occupy much of the doctrinal sociologists' time, the same cannot be said about the time and energy they expended involving themselves in political and social debates. "Science for action" was as much the Semaines sociales' motto as it was that of every intellectual devoted to the "restoration" of a Christian social and economic order (Gaudreau 1946). Convinced that the fate of modern civilization was sealed, that religious, economic, and social liberalism irremediably led to chaos, doctrinal sociologists launched diverse enterprises in order to alleviate the conditions of the poor and to address their most pressing needs.

To transform society [remembered Eugene Buissière] to bring new hopes to the French Canadian youth that grew up in the crisis of the 1930s and bring about deep change, such was our ideal, such was our objective. (Buissière 1988:36)

Situating themselves between a tainted capitalism and a vicious socialism (the French wording is more eloquent: "Entre un capitalisme vicié et un socialisme vicieux," Lévesque 1933:91), they attempted to establish a third way which would reconcile the respect due to each individual's freedom and the preservation of legitimate authority and order. They belonged to the political right when it came to the protection of private property, consolidation of social hierarchies, and promotion of traditions, and yet they also participated in a leftist sensibility when it came to supporting social legislation and denouncing the devastating effects of unbridled capitalism (Foisy-Geoffroy 2004). The majority sided with 
nationalists who denounced the economic and political confinement of French Canadians, oppressed in their own territory by the Anglo-Saxon elite.

It was while plunged into action that doctrinal sociologists felt the need to study sacred established principles promulgated by the Church, and it was in reading books that they became convinced of the necessity of committing themselves to social change. They were as active in trying to transform their community as they were theoretically and morally rigid in their interpretation of Pontifical Encyclicals. Their aim was to Christianize French Canada, not only in its religious faith, but in its economic, social, and cultural components. Some became professors in colleges and universities, but the vast majority found positions in various social movements, working as union leaders, co-operative managers, or journalists, trying to infuse the assumed universal principles deduced from the Pope's teachings into particular situations and contexts. Vocal critics of the existing social order, they turned to research only to find some minimal justification for transforming Quebec society in conformity with a Christian vision. Their moralism, then, did not entirely negate their desire to find concrete solutions to society's ills. Convinced of the need to agitate in favour of social reforms, doctrinal sociologists found in hospitals, orphanages, unions, or factories different fields in which to exercise their expertise.

Universities were also targeted. In a time of pressing needs and univocal moral beliefs, sociologists were defined as social activists much more than academic scholars. In the 1940-41 Laval University Calen$d a r$, it was stipulated that the School of Social, Political, and Economic Sciences provided students with a sound training based on Christian doctrine and Thomist philosophy. This would prepare them well for their lives as social apostles.

In particular, the School wishes to prepare those who propose to enlighten and guide Society by their writings or orally, or by exercising public functions, e.g. future reporters, professors, professional chaplains, social apostles, political leaders, etc. (Université Laval 1940:147).

During the interwar years nascent sociology programs were established, courses were taught, and some empirical research on French Canada was initiated by faculty members, yet, this evolution towards greater institutionalization and specialization was hindered by their particular understanding of the role and function of sociology. Social science was not encouraged for its own sake or for the pure joy of expanding the frontiers of human knowledge. Quite the opposite; with the emphasis placed on 
action at the expense of almost everything else, an academic sociology could not fully develop before a new acceptance of sociology emerged.

\section{Laval Sociology}

The Laval school of sociology initially took roots within the Faculty of Social Sciences at Laval University in the 1940s, and eventually spread to other colleges and universities. The arrival of Guy Rocher, hitherto a Laval professor, as chair of the Université de Montréal's Department of Sociology in 1960 represents an unequivocal indicator of the change. This school of sociological thought has sometimes been heralded as the first truly modern approach to the study of society in the history of Quebec, with the lone exception of Léon Gérin. Laval professors helped marshal the idea that scientific inquiry into French Canada began only with their arrival. In their view, the doctrinal sociologists belonged to an inferior and prehistoric form of social practice (Bourque 1993:46). Although I disagree with this view, it must be said that the Laval school realized such a complete union of the three axes of sociological practice that it still stands today as an ideal moment in the history of Quebec social science. For the first - and perhaps the only - time, the detached gathering of empirical facts by academic scholars constituted in and of itself a political engagement against the current state of affairs in the province.

During the 1940s and 1950s, Laval sociologists were literally obsessed with the question of data collection. "Research! Research! Always more research!" wrote Jean-Charles Falardeau (1988:11) to sum up his colleagues' priority. They undertook various research programs in order to understand more accurately the transformation of French Canadian families, launched a series of social inquiries, set up quantitative and qualitative methodology courses, and, in brief, did everything they could to organize the faculty of social sciences on a firm empirical basis. They encouraged students to adopt a scientific mindset and look at their society in an utterly detached fashion. Toward that end, they asked their students to stroll around the streets of Quebec City, notepad in hand, and simply observe the details of city life. Falardeau called his method learning sociology with one's feet (Gagnon 1988:83-86; Falardeau 1974). Sociology began with an effort to liberate oneself from any preconceived ideas and objectively study the surrounding world.

Their clash with doctrinal sociologists was violent. For one thing, learning sociology with one's feet meant that one had to refuse the old perspective which started from principles and ended with facts. The 
Christian doctrine was never abandoned, yet it no longer played a role in research. Scientific work was divided in two completely separate activities: a descriptive activity, which consisted in observing and classifying social phenomena; and a normative activity, which consisted in judging those facts according to a higher philosophy. Between seeing the world as it is or the world as it should be, sociology had to choose the former, from then on dissociating itself from any moralizing attitude (Delos 1934:15). Doctrinal sociologists could not conceive such a radical dissociation of the study of social functions and metaphysics, and accused Laval sociologists of betraying the role of a truly Catholic science, but to no avail (Clément 1949). The "materialist" teaching of sociology gained ground (Tremblay and Faucher 1951).

Laval sociologists' vibrant appeal to empiricism masked the ideological nature of their commitment to research. Citing an article written by Léon Dion and published in Cité libre in 1958 (Dion 1958), some historians emphasize the sociologists' reluctance in the 1950s to take political stands (Lévesque et al. 1988). Indeed, in his essay, Dion defended the right of scientists to stay away from public clamour and warned his colleagues against accepting solicitations from the rest of society (Dion 1958). Yet, to recall Falardeau's words, public involvement and research were two sides of the same coin for Laval sociologists (Falardeau 1959:6), and his peers were strongly committed to the issues of their day while pursuing their academic careers. Who more than Dion represents the ideal of an engaged intellectual entangled in the numerous debates of his time? In fact, an impressive number of students who graduated from Laval University in the 1940s and 1950s joined the provincial or federal governments and were amongst the most zealous reformers of the 1960s and 1970s (Guy Coulombe, Jean-Claude Lebel, Roger Marier, Claude Morin, Louis Robichaud), taking part in royal commissions, writing ministry reports, and overseeing national surveys, when they were not simply running for office. The studies they conducted or sponsored during the Quiet Revolution (1960-1980) were inspired by a desire to reform society from top to bottom and radically modify the prevailing order.

It is a sociology that has rolled up its sleeves and that has not been afraid to grasp the true complex, human, concrete, crucial problems. It is an active sociology that has opted against the status quo, in favour of change, in favour of democracy, and that has used its scientific insights to find the most efficient and most intelligent means to realise those choices. (Chabot et al. 1965:9)

The Laval sociologists' political and social engagement can be summed up by referring to three crises: the debate over secularization, 
the Asbestos Strike, and the Massey Commission. Because Laval sociologists accepted the need to secularize Quebec society and open the door to the involvement of the Catholic laity, they were accused of being atheists and freemasons. When they sided with the workers during the Asbestos Strike and other union protests in the 1940s and 1950s, they were criticized for their communist sympathies. And finally, when they embraced the federalist model of social organization and turned their backs to traditional French Canadian nationalism, they appeared to some as traitors to their own people. Anticlerical, socialist, and federalist, they embodied everything the clericalist, corporatist, and nationalist doctrinal sociologists had fought against in the 1930s. The contrast could not have been more vivid and the resistance to their teaching more blatant.

Denouncing Dean Lévesque's overt activism, the premier of the province, Maurice Duplessis, went as far as to threaten to terminate government funding to Laval's faculty of social sciences (Black 1977:372375; Warren 2003:246). Had the faculty and students not actively campaigned in favour of anti-clerico-nationalist ideologies, little of the animosity it attracted would have emerged. Robert Rumilly, an intellectual well known for his conservative views, wrote in 1956:

Everybody knows the spirit in which Father Georges-Henri Lévesque ... has organized the Faculty of social sciences at Laval University. He transformed it into a haven for leftist thought. (Rumilly 1956:106)

Extremist as it was, Rumilly's statement was not entirely false. Not only two conceptions of science but two conceptions of the Christian doctrine conflicted with one another in the aftermath of the Second World War, one based on traditionalist ideals (Trépanier 1995) and the other based on personalist ideals (Gauvreau 2005).

In 1960, with the election of Jean Lesage, a clerical French Canada officially ceded its place to a state-controlled Quebec, so to speak, and a well-trained laity took over, in particular in the education system (Guindon 1998). The provincial government increasingly drew on science and technology for the knowledge and expertise needed to organize Quebec society in a competitive modern world. Fulfilling a coordinating function within the government apparatus, the social sciences' task seemed detached from any political involvement but, in reality, it was profoundly involved in state building. In conjunction with the development of the techno-scientific complex, the rational organization of the public sphere, and the growth of technocracy, they widened their field of practice during the same period that they entered into the state bureaucracy as experts. Sociology's newly found role in public governance justified the hiring of an army of full-time sociologists. "Experts in hu- 
man behaviour and social manipulators are multiplying like rabbits ..." (Simard 1979:38). The more numerous they were, the more they could define social problems, and the more social problems were categorized, analyzed, and publicized, the more sociologists could justify their trade. It helped, of course, that the Quiet Revolution was a time of widespread social reengineering, when everything, from the family to the economy, had to be retooled, revamped, rethought, revisited, reconstructed. The Quiet Revolution turned sociology into an expertise galvanized by the ideal of service to the nation.

What is important to underscore here is that social scientists proposed closing the cultural gap which separated nationalist and corporatist ideas from industrialized and urbanized reality. By revealing the modernized state of their society they claimed they could objectively refute the mythology that had served as French Canadian collective consciousness for close to a century. The doctrinal sociologists had argued that French Canadians were a rural, Catholic, and European-leaning people. The Laval sociologists spent much of their time demonstrating that most French Canadians were, in fact, urban (Falardeau 1953), boasted only a very superficial faith (Moreux 1969), and participated in an Americanized culture (Fortin 1971). Because such an empirical description of reality represented in and of itself a critique of the dominant discourse, Laval sociologists thought themselves apolitical - although, of course, they weren't. Fernand Dumont recalls that the Laval social sciences students and faculty were under the impression they lived in an "ideological void" (Dumont 1974:19). "Setting aside traditional speculations, we went in search of an objective awareness" (Dumont 1974:19). By accumulating a positive scientific knowledge of its past and present, they believed it possible to vanquish outdated representations and see French Canada as it truly was, setting the stage for a more adapted and functional future. Therefore, in their minds, the search for objectivity was also a quest for normalcy (Rudin 1997).

The image of sociologists as researchers came to prominence during this period. They were trusted with important responsibilities in growing state organizations, provoking a massive surge in student enrolments in social sciences faculties (Gingras and Warren 2007). Considering the key role social scientists could play in implementing its social policies, the state opened its doors to people who had earned their graduate degrees in faculties of social sciences. As well, the provincial government funded the Quebec university system so it could adequately train its own labour force, creating the necessary conditions for the blossoming of several academic research centres (Fournier 1973; Almeida 2007). In other words, in the broad governmental oversight of education, work, 
health, and all sectors connected to human development more generally, sociology found a purpose - along with psychology, economics, and other social sciences - in the drafting and implementation of state policies, which in turn guaranteed academic recognition for its students and faculty. In contrast to the interwar years, when distinguished intellectuals came from backgrounds in theology and history, the 1960s witnessed the rise to public prominence of sociologists and political scientists (Fournier 1973; Brooks and Gagnon 1988).

Sociologists could believe they were being critical of their society just by publishing dry "neutral" reports, and do so from the position of university professors, thereby reconciling the three fundamental facets of their discipline: in their work, they were inseparably public intellectuals, positivist researchers, and academic faculty. This specific conjuncture - when the analysis of society, taken up by well paid and highly regarded professionals, was spontaneously a critique of nationalist and religious reactionary forces - corresponded to a "golden age" in the history of Quebec sociology (Fournier 1999:303). Offering their services to universities in a time of rapid growth, sociologists directly linked their most detached empirical observations with their strongest intellectual commitments, and could do so while occupying valued institutional positions (Dumont 1973). To a certain extent, research was simultaneously an ideology and a career-path.

\section{A Complex Equilibrium}

The lesson that can be drawn from this brief presentation of the history of French Quebec is that sociology always composes and recomposes the three specific axes of its practice, and that equilibrium is rarely achieved. Sociological schools never entirely neglect concrete observation, ignore social debates and issues, or forget the need to foster sociology as a wellestablished profession. However, they often overemphasize one or the other of these three aspects. The Le Playsian method insisted on data collection to the highest degree, publishing monographs in which a family's budget was scrutinized in minute details. Gérin was very much concerned by his nation's fate; yet he never went beyond the writing of a few newspaper articles and, on his farm, presented himself as an example of what French Canadians must achieve. He did not really contemplate the idea of teaching at the university level and contented himself - for a few years - with leading a study circle in Ottawa. Sociology was, for him, not a profession but an attitude. In contrast, doctrinal sociologists were much more directly engaged in the concerns of society. They took public 
positions during the 1929 Crash, the Second World War, the Conscription crisis, the compulsory schooling debate, the Bloc populaire's campaigns, and so forth. They relentlessly criticized what they regarded as a failed liberal system, denouncing workers' miserable living conditions and the harmful decline of the Church's authority in human affairs. Their propagandist tendencies led them to stay away from the universities' ivory towers. Why would Quebec social scientists confine themselves to the academy when so much had to be done outside campus? For that reason, the doctrinal sociologists also undertook few empirical studies.

In describing the difficult art of combining the three dimensions of sociological practice, I did not include a third possibility: the overemphasis of professional activity at the expense of empirical research and public engagement. Before the 1960s, Quebec universities had not developed into a relatively autonomous microcosm where individuals could pursue a prolific career. Academic conferences were in their infancy, specialized journals were scarce (Recherches sociographiques was founded in 1960), and invitations to collaborate with foreign colleagues almost nil. Graduate doctoral studies did not exist at Université de Montréal, and only marginally at Université Laval. Research centres had not yet evolved into prestigious and well-funded collaborative international forums. Consequently, their teaching assignments notwithstanding, faculty could not spend the better part of their time trying to elevate themselves to a high position in academia, whether by accepting to serve as editor-in-chiefs, chairs or deans, directors of research centres, conference organizers, editors of collectives, directors of undergraduate studies programs, presidents of round-tables, evaluators of grant proposals, etc. Such a performance of their duties, which might certainly incorporate political and empirical aspects, will always be welcomed to the extent that scientific knowledge can no longer do without it. However, before the 1960s, the academic world was insufficiently developed to fully nourish such ambitions. The discipline's institutionalization accompanied a move to achieve a certain degree of professionalization, but the move was slow and even today has not been accomplished to the same degree it has been achieved in other more practical sectors (Gingras 1991).

Many contemporary observers denounce the lack of objectivity in the contemporary social sciences or their fragile institutionalization. Quebec sociology's foundations were shaken by the successive collapse of functionalism, structuralism, and in particular Marxism, which had gained enormous ground in the 1970s (Warren 2007).

The new generations, sceptical vis-à-vis a form of pure modernism which would have liberated Quebec from tradition and put it under the patron- 
age of an absolute reason, breaks with a certain materialistic positivism widespread in the 1960s. (Beaudry and Chevrier 2007:25)

Without altogether abandoning the quest for objectivity, some young scholars have adopted an interpretation of cultural studies that aims at developing contingent and historically limited truths only (Warren 2006). The underfunding of Quebec universities has stirred discussions concerning the incapacity to hire faculty, sponsor graduate students, publish journals, organize symposiums, and strengthen networks. Since well-funded scholars have a greater chance of being considered serious academics by their administration and receiving recognition from their peers, the race for productivity has created a competition for resources. The elaboration of specific strategies to gain the greatest benefit from university funding (integration of research teams, choice of fashionable objects of study, etc.) has only exacerbated the French Quebec sociologists' present difficulties in academic performance. The movement by SSHRC and FRSC toward a "knowledge economy" (Renaud 1999) has contributed to mounting frustration associated with an "economy of knowledge."

As far as can be judged from a quick survey of recent publications (Labelle 2002:427), most Quebec observers deplore not the sociologists' lack of professional success or their scant harvest of empirical research, but their feeble social and political engagement - a complaint that can be traced back to the early 1980s (see Soulet 1987; Fournier 1991). Sounding much like Burawoy in the United States, they claim that sociologists do not sufficiently involve themselves in public debates. Indeed, they find that the majority of sociologists holds to the view that sociology is and should be politically, normatively, and critically disengaged. Slowly, they are transforming it into "pure and simple techniques of operational 'management' of the 'social'" (Freitag 1987:116). In these circumstances, many commentators are calling for the development of a politicized scientific knowledge (Kelly 2002), which would extend the French Canadian sociological tradition of critical reflexivity and orient the march of contemporary Quebec society.

We must, more than ever before [affirms Michel Freitag] keep our distance from a logic of operational management.... We must convince ourselves that our primary task is to shed some light on the normative issues raised by the organization of the social order. (Freitag 1998:217).

It is interesting to note that this determination to accentuate sociology's public engagement seems to be emphasized to the detriment of the other two dimensions of sociological practice. On one hand, people 
complain about the production of detached, disconnected empirical research that serves only the pure advancement of knowledge; wishing sociology could be both relevant and true, they see the constitution of the academic ivory tower as a major flaw in today's universities (Kelly 2002). In their view, the neglect of teaching to the benefit of research sometimes serves as a measure of a misguided institutionalization (Gingras 1987). One effect of this internal dynamic is that graduate students who should be preparing themselves to enter the job market are often trained to become university scholars. On the other hand, and in concert with the first accusation, they denounce Quebec universities as corporatist bodies serving not the greater good but the immediate interests of their faculty and staff. They lament that a proper equilibrium has not been kept between the need for research, the need for professional success, and the need for social critique (Gingras 1991). Enviously looking back at the "golden age" of sociology, they are searching for a way to integrate the three "moments" of sociological practice. Whether they put the blame on funding agencies, an academic managerial revolution, an epistemological shift, or a dominant neoliberal ideology (Fontan 2000; Piotte 2000), they all believe that sociology's critical function in society is being challenged as never before.

This brief history of French Quebec sociology shows that the struggle to harmonize the discipline's professional, descriptive, and political aspects represents a recurrent legitimization question in the discipline. Moreover, it teaches us that the successful intertwining of data gathering, career promotion, and social engagement is an extremely complex endeavour. Pushing towards greater specialization may reduce the possibility for public criticism, just as a narrow focus on empirical studies may diminish the radical potential for a critical sociology. Indeed, the Quiet Revolution enabled sociologists to work in a professional capacity towards empirical research and social revolution at the same time. The 1960s Quebec sociologists evolved in an exceptional period, when the observation of reality was at the same time, in and of itself, a critique of prevalent ideologies, and a visa to a well-paid job in the university. But measuring today's sociology by such a standard is misleading. Only once in the last hundred years have Quebec sociologists reconciled so perfectly the three aspects of their discipline. Entertaining nostalgia for this era will not bring it back. Quebec sociologists must accept the autonomy of their discipline's three fundamental traits, and, while constantly working to reconcile them, avoid simply deploring a division which was, is, and will forever be at the heart of their practice. 


\section{REFERENCES}

Almeida, Mike. 2007. Comment se rendre utile: les centres de recherche universitaires en sciences sociales au Canada. Scientia Canadensis 30(2):97122.

Barbeau, Victor. 1936. Mesure de notre taille. Montréal: Le Devoir.

Beaudry, Lucille and Marc Chevrier. 2007. Pensée critique, conservatisme ou libéralisme? Considérations sur l'horizon politique et philosophie de la "nouvelle sensibilité." Pp. 9-30 in Lucielle Beaudry and Marc Chevrier, eds., Une pensée libérale, critique ou conservatrice? Actualité de Hannah Arendt, d'Emmanuel Mounier et de Georges Grant pour le Québec d'aujourd'hui. Montréal: Les Presses de l'Université Laval.

Black, Conrad. 1977. Duplessis. Vol. 2, Le pouvoir, Montréal: Éditions de l'Homme.

Blau, Judith and Keri Iyall Smith, eds. 2006. The Public Sociologies Reader. Rowman \& Littlefield.

Bourdieu, Pierre. 2004. Science of Science and Reflexivity. Chicago, University of Chicago Press.

1975. La spécificité du champ scientifique et les conditions sociales du progrès de la raison. Sociologie et sociétés 7(1):91-118.

Bourque, Gilles. 1993. Société traditionnelle, société politique et sociologie québécoise, 1945-1980. Cahiers de recherche sociologique 20:45-83.

Brooks, Stephen and Alain G. Gagnon. 1988. Social Scientists and Politics in Canada: Between Clerisy and Vanguard. Montreal and Kingston: McGill-Queen's University Press.

Bussière, Eugiène. 1988. L'éducation des adultes à l'Université Laval. Pp. 35-53 in Albert Faucher (dir.), Cinquante ans de sciences sociales à l'Université Laval. Sainte-Foy, Faculté des Science Sociales de l'Université Laval.

Burawoy, Michael. 2005. 2004 Presidential Address: For public sociology. American Sociological Review 70(1):4-28. 2004. Public sociologies: contradictions, dilemmas, and possibilities. Social Forces 82(4):1603-1618.

Carrier, Hervé. 1960. Le sociologue canadien Léon Gérin : sa vie, son œuvre, ses méthodes de recherche. Montréal: Bellarmin.

Chabot, Jean-Louis, Nicole Laurin, Jean-Guy Frenette and Louise Whitby, 1965. Les sociologies, des révolutionnaires? Allons donc! Le Quartier latin, February 23:9.

Clawson, Dan, Robert Zussman, Joya Misra, Naomi Gerstel, and Randall Stokes, eds. 2007. Public Sociology: Fifteen Eminent Sociologists Debate Politics and the Profession in the Twenty-First Century. Berkeley: University of California Press.

Clément, Marcel. 1949. Sciences sociales et catholicisme. Montréal: L'École Social Populaire, no 423. 
Couture, Claude and Claude Denis. 1994. La captation du couple tradition-modernité par la sociographie québécoise. Pp. 105-131 in Terry Goldie, Carmen Lambert and Rowland Lorimer, eds., Canada: Theoretical Discourse/Discours théoriques. Montréal: Association des Études Canadiennes.

Delos, J.-T., 1934. Introduction. Pp. 7-21 in A. Lemonnyer, J. Tonneau and R. Troude, Précis de sociologie. Marseille: Publiroc.

Dion, Léon. 1958. Aspects de la condition du professeur d'université dans la société canadienne-française. Cité libre 21, July, pp. 8-30.

Dumont, Fernand. 2000. Entretiens Un témoin de l'homme. Montréal: L'Hexagone.

-1981. L'Anthropologie en l'absence de l'homme, Paris, Les Presses Universitaires de France.

1974. The Vigil of Quebec. Toronto: University of Toronto Press.

1973. Chantiers. Essais sur la pratique des sciences de l'homme. Montréal: Hurtubise-HMH.

Dumont, Fernand and Jean-Charles Falardeau, 1960. Pour la recherche sociographique au Canada français. Recherches sociographiques 1(1):3-5.

Dupuis, Jean-Claude, 1991. La pensée sociale d'Arthur Saint-Pierre. Bulletin du regroupement des chercheurs-chercheures en histoire des travailleurs et travailleuses du Québec, XVII(1):25-61.

Durkheim, Emile. [1893] 1967. De la division du travail social. Paris: Les Presses Universitaires de France.

Falardeau, Jean-Charles. 1988. La Faculté du Cap-Diamant. Une genèse et une réussite. Pp. 15-33 in Albert Faucher, ed., Cinquante ans de sciences sociales à l'Université Laval. L'histoire de la Faculté des sciences sociales (1938-1988). Sainte-Foy: Faculté des sciences sociales de l'Université Laval.

1974. Itinéraire sociologique. Recherches sociographiques XV(23):213-227.

1959. Lettre à mes étudiants. Cité libre 23:4-14.

- ed. 1953. Essais sur le Québec contemporain. Sainte-Foy: Presses de l’Université Laval.

Foisy-Geoffroy, Dominique. 2004. Esdras Minville. Nationalisme économique et catholicisme social au Québec durant l'entre-deux-guerres. Québec: Éditions du Septentrion.

Fontan, Jean-Marc. 2000. De l'intellectuel critique au professionnel de service, radioscopie de l'universitaire engagé. Cahiers de recherche sociologique 34:79-98.

Fortin, Gérald. 1971. La fin d'un règne. Montréal: HMH.

Fournier, Bernard. 1991. L'intellectuel engagé et le chercheur scientifique : deux figures antagonistes? Pp. 471-491 in Raymond Hudon and Réjean Pelletier, eds., L'Engagement intellectuel. Mélanges en l'honneur de Léon Dion. Sainte-Foy: Les Presses de l'Université Laval. 
Fournier, Marcel. 2001. Quebec sociology and Quebec society: The construction of a collective identity. The Canadian Journal of Sociology 26(3):333347.

1999. Notes pour une histoire de la sociologie québécoise suivies d'éléments de réflexions sur l'avenir. Pp. 287-322 in Robert Lahaise, ed., Québec 2000. Montréal: HMH.

1986. L'entrée du Québec dans la modernité : science, culture et société au Québec. Montréal: Éditions Saint-Martin.

1985. La sociologie dans tous ses états. Recherches sociographiques 26(3):417-443.

1973. L'institutionnalisation des sciences sociales au Québec. Sociologie et sociétés 5(1):27-57.

Freitag, Michel. 1987. La crise des sciences sociales. Entre épistémologie et idéologie, la place de la question de la normativité dans le développement de la connaissance de la société. Société 1:83-151.

1998. Débat: La sociologie a-t-elle encore aujourd'hui une capacité normative? Cahiers de recherche sociologique 30:249-298.

Gagné, Gilles and Jean-Philippe Warren. 2005. Sociologie et valeurs. Quatorze penseurs québécois du XXè siècle. Montréal: Presses de l'Université de Montréal.

Gagnon, Nicole. 1988. Le Département de sociologie, 1943-1970. Pp. 76-130 in Albert Faucher, ed., Cinquante ans de sciences sociales à l'Université Laval. L'histoire de la Faculté des sciences sociales (1938-1988). Sainte-Foy: Faculté des sciences sociales de l'Université Laval, .

Gaudreau, Marie-Agnès de Rome. 1946. La Pensée sociale du Canada français telle que reflétée dans les Semaines sociales. Montréal: École sociale populaire.

Gauvreau, Michael. 2005. The Catholic Origins of Quebec's Quiet Revolution, 1931-1970. Montréal and Kingston: McGill-Queen's University Press.

Gérin, Léon. 1938. Le type économique et social des Canadiens. Milieux agricoles de tradition française. Montréal: Éditions de l'A.C.F.

1913. Errol Bouchette. Mémoires de la Société Royale du Canada, 3ème série, VII, section 7, v-x.

1908. A quoi bon l'action sociale? L'Action sociale 16(4).

1905. La vulgarisation de la science sociale chez les Canadiens français. Mémoires de la Société Royale du Canada, 2ème série, vol. XI, 67-87. 1895. Controverse sociale, I, II et III. Le Monde (Montréal), 18 et 26 janvier, et 2 février.

Gingras, Yves, 1991. L'institutionnalisation de la recherche en milieu universitaire et ses effets. Sociologie et sociétés 23(1):41-54.

1987. Le défi de l'Université moderne : l'équilibre entre l'enseignement et la recherche. Possibles 11(4):151-163.

Gingras, Yves and Jean-Philippe Warren. 2007. Job market boom and gender tide: The rise of Canadian social sciences in the 20th century. Scientia Canadensis 30(2):5-22. 
Guindon, Hubert. 1998. Chronique de l'évolution sociale et politique du Québec depuis 1945. Cahiers de recherche sociologique 30:33-78.

Heilbron, Johan, Remi Lenoir, and Gisèle Sapiro. 2004. Pour une histoire des sciences sociales. In Johan Heilbron, Remi Lanoir and Gisèle Sapiro, eds., Pour une histoire des sciences sociales. Hommage à Pierre Bourdieu. Paris: Fayard.

Kalaora, Bernard and Antoine Savoye. 1989. Les inventeurs oubliés : Le Play et ses continuateurs aux origines des sciences sociales. Paris: Champ Vallon.

Kelly, Stéphane, ed. 2002. Les idées mènent le Québec : essais sur une sensibilité historique. Sainte-Foy: Presses de l'Université Laval.

Labelle, Gilles. 2002. Review of Pierre Hébert, La nouvelle université guerrière, Québec, Nota bene, 2001. Recherches sociographiques 43(2):427-429.

Lamonde, Yvan. 2004. Histoire sociale des idées au Québec (1896-1929). Montréal: Fides.

1980. La philosophie et son enseignement au Québec (1665-1920). Montréal: Hurtubise-HMH.

Lévesque, Georges-Henri. 1983. Souvenances. Montréal: La Presse. 1933. Socialisme canadien. La CCF. L'Action nationale II:91-116.

Lévesque, Georges-Henri et al., eds. 1988. Continuité et rupture. Les sciences sociales au Québec. Montréal: Presses de l'Université de Montréal.

Méline, Pierre, P. 1912. G.F. Le Play, auvre de science. Paris: Librairie Bloud.

Minville, Esdras. 1938. Quelques aspects du problème social dans la province de Québec. L'Actualité économique 1(7):401-424.

Montpetit, Édouard. 1907. Question sociale et Ecoles sociales. Ecole catholique. Le Semeur III(10):281-289.

Moreux, Colette. 1969. Fin d'une religion? Montréal: Les Presses de l'Université de Montréal.

Périer, Philippe. 1951. L'étude des groupements sociaux d'après Léon Gérin. Les Études sociales December, 1-7.

Piotte, Jean-Marc. 2000. L'université, les universitaires et la gauche. Cahiers de recherche sociologique 34:5-24.

Renaud, Marc. 1999. Notes du discours prononcé par Marc Renaud, président du CRSH, à la 30e conférence Sorokin annuelle.

Robert, Arthur. 1922. La morale et la sociologie. Mémoires de la Société Royale du Canada XVI:91-108.

Routhier, Gilles. 1981. L'ordre du monde. Capitalisme et communisme dans la doctrine de l'École sociale populaire, 1930-1936. Recherches sociographiques XXII(1):7-48. 
Rudin, Ronald. 1997. Making History in Twentieth Century Quebec. Toronto: University of Toronto Press.

Rumilly, Robert. 1956. L'Infiltration gauchiste au Canada français. Montréal: [Compte d'auteur].

Simard, Jean-Jacques. 1979. La longue marche des technocrates. Laval: Editions Coopératives Albert Saint-Martin.

Soulet, Marc Henry. 1987. Le silence des intellectuels; radioscopie de l'intellectuel québécois. Montréal: Éditions Saint-Martin.

Tardif, P. 1920. Influence sociale de l'eucharistie. Le Devoir, June 22, 5.

Tremblay, Maurice and Albert Faucher. 1951. L'enseignement des sciences scociales au Canada de langue française. Pp. 191-203 in Les arts, lettres et sciences au Canada, 1949-1951. Ottawa: Edmond Cloutier.

Trépanier, Pierre. 1995. Esdras Minville (1896-1975) et le traditionalisme canadien-français. Les Cahiers des dix 50:255-294.

Université Laval. 1940. Annuaire de l'Université Laval, Québec, L'Action Sociale Limitée, 1941.

Warren, 2002. La découverte de "la question sociale." Revue d'histoire de l'Amérique française LV(4):539-572.

Warren, Jean-Philippe. 2008. Une douce anarchie. Les années 68 au Québec. Montréal: Boréal.

2007. Ils voulaient changer le monde. Le militantisme marxiste-léniniste au Québec. Montréal: VLB.

2006. La sociologie québécoise aura-t-elle succombé (sans qu'elle le sache) au Cultural Studies? Bulletin d'histoire politique 14(1):237-247. 2003. L'Engagement sociologique. La tradition sociologique du Québec francophone. Montréal: Boréal.

2002. La découverte de la "question sociale." Sociologie et mouvements d'action jeunesse canadiens-français. Revue d'histoire de l'Amérique française 55(4):539-572.

Dr. Jean-Philippe Warren holds the Concordia Chair for the Study of Quebec in the Department of Sociology and Anthropology. He has published extensively and was awarded the Michel-Brunet prize and the Clio Prize in 2003. His most recent books include Ils voulaient changer le monde. Le militantisme marxisteléniniste au Québec (2007) and Les Années 68 au Québec. Le mouvement étudiant québécois dans la tourmente anarchiste (2008). A multidisciplinary scholar, his work has appeared in literature, philosophy, anthropology, sociology, political science, as well as history journals. His main research interests revolve around epistemology, popular culture, sociological theory, and social movements. 
